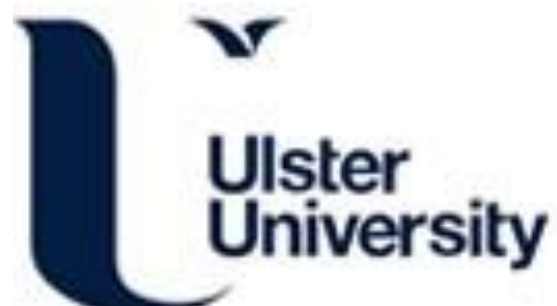

\section{Supporting community cohesion through ICT: The epartners programme in Northern Ireland}

Austin, R., Hunter, B., \& Hollywood, L. (2015). Supporting community cohesion through ICT: The epartners programme in Northern Ireland. Computers in Human Behaviour, 52, 508-514.

https://doi.org/10.1016/j.chb.2015.02.039

Link to publication record in Ulster University Research Portal

\section{Published in:}

Computers in Human Behaviour

Publication Status:

Published (in print/issue): 30/11/2015

DOI:

10.1016/j.chb.2015.02.039

\section{Document Version}

Publisher's PDF, also known as Version of record

\section{General rights}

Copyright for the publications made accessible via Ulster University's Research Portal is retained by the author(s) and / or other copyright owners and it is a condition of accessing these publications that users recognise and abide by the legal requirements associated with these rights.

\section{Take down policy}

The Research Portal is Ulster University's institutional repository that provides access to Ulster's research outputs. Every effort has been made to ensure that content in the Research Portal does not infringe any person's rights, or applicable UK laws. If you discover content in the Research Portal that you believe breaches copyright or violates any law, please contact pure-support@ulster.ac.uk. 


\title{
Supporting community cohesion through ICT: The epartners programme in Northern Ireland
}

\author{
Roger Austin ${ }^{a}$, Bill Hunter ${ }^{\mathrm{b}, *}$, Lynsey Hollywood ${ }^{\mathrm{c}}$ \\ ${ }^{a}$ Education Department, University of Ulster (Coleraine campus), Co. Londonderry BT52 1SA, United Kingdom \\ ${ }^{\mathrm{b}}$ Faculty of Education, The University of Ontario Institute of Technology, 11 Simcoe St N., PO Box 385, Oshawa, ON L1H 7L7, Canada \\ ${ }^{c}$ Consumer Studies, Department of Hospitality and Tourism Management, University of Ulster (Coleraine campus), Co. Londonderry BT52 1SA, United Kingdom
}

\section{A R T I C L E I N F O}

\section{Article history:}

Available online $\mathrm{xxxx}$

\section{Keywords:}

Online learning

Community cohesion

Conflict reduction

\begin{abstract}
A B S T R A C T
In the face of deep-rooted sectarian sentiment in Northern Ireland and the pervasive nature of "separateness" between the Protestant and Catholic communities, this article examines school projects designed to promote community cohesion and assesses the role that information and communications technology (ICT) can play to encourage collaboration within a social psychology framework. Further, we report on exploratory research conducted through the evaluation of a pilot program that involved university student tutors working with teachers and pupils in a range of schools. Our findings to date suggest that a strong focus on collaborative work in non-contentious areas of the curriculum has a strong chance of securing support from key stakeholders, including teachers, the main churches and other stakeholders in the educational system.
\end{abstract}

(c) 2015 Elsevier Ltd. All rights reserved.

\section{Introduction}

In this paper, we assess recent efforts to address one of the most deep-rooted problems on the island of Ireland by examining an ICT project called "epartners." For centuries, the people of Ireland have been divided over intertwined issues related to religion (Catholic vs. Protestant) and to relations with Great Britain. In recent decades, the tensions around these issues have been most acute in Northern Ireland which remains a part of the United Kingdom. This project links Catholic and Protestant schools within Northern Ireland in an attempt to provide a prototype for reaching all schools in Northern Ireland.

One of the most striking features of sectarianism on the island of Ireland is the depth of its roots, with animosity and intercommunal violence between Catholics and Protestants reported as long ago as the late eighteenth century. An Irish historian writing in 1892 noted that "If the characteristic mark of a healthy Christianity be to unite its members by a bond of fraternity and love, then there is no country where Christianity has more completely failed than Ireland" (Lecky, 1892).

At various points since then, attempts to address the root causes of conflict have included efforts to see how schools might play a part in enabling the next generation to set aside their differences

\footnotetext{
* Corresponding author. Tel.: +1 7052526880.

E-mail addresses: rsp.austin@ulster.ac.uk (R. Austin), bill.hunter@uoit.ca (B. Hunter), l.hollywood@ulster.ac.uk (L. Hollywood).
}

in the interests of social cohesion. For example, in 1831 the British administration of Ireland set up a national school system with the principal aim of uniting "in one system children of different creeds" (Akenson, 1970, p.158). According to Hyland (1989) these noble aspirations were undermined within twenty years by the main Christian churches whose leaders campaigned to have schools under their own distinct control. By 1850 only $4 \%$ of the schools were genuinely mixed in religious affiliation and this was a pattern that continued after the partition of Ireland in 1921. The creation of two states, Northern Ireland and the Republic of Ireland, not only left a legacy of suspicion between north the south, it also sharpened divisions within Northern Ireland between those who wished to strengthen links with the rest of the United Kingdom (primarily Protestants) those who aspired to a united Ireland free from British rule (primarily Catholics).

The extent to which people lead separate lives in Northern Ireland (e.g., Hargie, Dickson, \& Rainey, 2002), is reflected in the make-up of political parties, housing patterns and preferences for different sports and culture, (Austin \& Anderson, 2008; Roulston, \& Young, 2013) and is clearly evident in the schooling system. Some $95 \%$ of children attend schools that remain predominantly Catholic or Protestant. We will examine literature related to past efforts to address Northern Ireland's through school-based interventions, describe our efforts to use universitybased tutors to assist teachers in using technology to enable diverse students to collaborate on school work, and indicate the challenges and possibilities for future uses of such an approach. 


\section{Review of work to address division between Catholic and Protestant schools within Northern Ireland}

As Duffy and Gallagher (2014) suggest, there have been a range of efforts, particularly since the 1980s, to find ways that schools might be encouraged to play a role on contributing to community cohesion.

\subsection{Integrated education}

In the 1980s, a group of parents set up the first "integrated school" in 1981 to educate children of all faiths (and none) together. The support for integrated education led to a provision in the 1989 Education Reform Order which placed a duty on the Department of Education in Northern Ireland to "encourage and facilitate" integrated education. (Department of Education, Northern Ireland, 1989). However, there was opposition to the integrated schools movement by the main churches, whose leaders wanted to retain the status quo; by some teachers, who feared for their jobs; and by some politicians, who claimed that there were already too many schools for the size of the population in Northern Ireland. Partly because of this, the number of pupils attending integrated schools reached only $7 \%$ of the school population by 2014 . (Northern Ireland Council for Integrated Education, annual report 2012/2013).

There have been three further noteworthy efforts to build bridges between schools since the 1999 introduction of political power-sharing between the republican/nationalist part of the community (which is mainly Catholic) and which has an overall aim that includes uniting Northern Ireland with the Republic of Ireland) and their unionist counterparts (who are predominantly Protestant) and who wish to remain within the United Kingdom.

\subsection{A common curriculum}

First, a common curriculum in Protestant, Catholic and Integrated schools means that every child in Northern Ireland can be expected to cover broadly the same history and, in citizenship courses, to study the need for respect for diversity and tolerance (Council for the Curriculum \& Assessment., 2014). But according to Barton and McCully (2012), young people from communities which have strongly held views about the past often struggle to connect the powerful narratives they hear in their own community with the more balanced version of history they hear in school. Furthermore, O'Connor, Beattie, \& Niens (2008), in a study of the effects of citizenship education in Northern Ireland, found that regardless of the intrinsic merits of the course content, the fact that pupils studied only with peers from the same side of the community as themselves was a limitation in the learning environment. More recently, in a detailed evaluation of the extent to which a shared curriculum could enhance community relations, Niens, Kerr, \& Connolly (2013) reported that there were notable differences between the schools which studied the same content but also had contact with one another as compared to schools that simply studied the same curriculum. Findings emphasized the benefits of having one curriculum to encourage cohesion rather than promote separation. One teacher was quoted as saying,

It doesn't matter what they teach you in school, but if you go home to your own community and you're still separate, and you never meet anybody that's any different from yourself, that's the way you're going to be. I don't think it should be solely left just in the hands of schools.

[Niens et al., 2013, p. 55]

Niens et al. (2013) concluded that while the curriculum has had the effect of making a difference to pupils' attitudes, there was considerable added value for both the pupils and teachers when contact was part of joint study of the curriculum. They noted that, the contact element of the programme has, patently, been successful in engaging schools; the lessons which were "shared" were predominantly reported as having gone very well in terms of pupil enjoyment, interaction and participation. Additionally, a majority of Curriculum + Contact teachers felt that the joint sessions were very positive exercises, particularly, in terms of learning from the other teacher's experience.

[Niens et al., 2013, p. 67]

\subsection{Shared education}

The second recent approach to promoting community cohesion has been through shared education. This is a government supported initiative defined as, "two or more schools from different sectors working in collaboration with the aim of promoting equality of opportunity, good relations, equality of identity, respect for diversity and community cohesion." (Connolly, Purvis, \& O'Grady, 2013 p. 7). For example, the Department of Education plans to build 10 new school campuses in which schools of different denominations have their own buildings but may share facilities (e.g., sports hall, gyms). The authors estimate that this solution might reach no more than $12 \%$ of the total school population given that the campuses are likely to cater for no more than 60 schools out of a total number of around 1200 schools. However, clusters of local schools have also been brought together in Area Learning Communities (Department of Education, 2013a) with the purpose of sharing expertise and resources.

A recent Department of Education survey across all schools in Northern Ireland sought to determine the extent to which the schools had participated in shared education. Seventy-six percent of respondents claimed to have been involved in such work but only sixty-five percent was cross-community. (Department of Education, 2013b, p. 8). It is also worth noting that a significant percentage of these links were with special schools, international or cross-border, rather than with schools of a different denomination within Northern Ireland.

Hughes (2014) further argued that even though shared education may have some positive effect on pupils, it remains problematic that teachers' reasons for participating are more focused on educational outcomes than on reconciliation. Duffy and Gallagher (2014), while noting some achievements of shared education pointed out that most of the work done to date involved the bussing of pupils from one school to another (or to neutral venues). It would appear that little or no use has been made of ICT within Northern Ireland to sustain partnerships between schools.

It seems clear that any plan to address the problems emanating from having separate schooling will need to be sustainable, costeffective and capable of garnering cross-community support. Crucially, to make a difference, any strategic plan would need to be capable of including every school in Northern Ireland in a cost-effective way and make use of effective "contact."

\subsection{Using technology to link schools}

Finally, the role of ICT in linking schools for community cohesion has been the focus for considerable recent research. Evidence has been emerging that the use of ICT to link schools across the border between Northern Ireland and the Republic of Ireland and elsewhere has been welcomed by teachers and started to have an impact on the skills and attitudes of young people. In the design of this work, the combination of the contact hypothesis (Allport, 1954) and the reach of the internet were found to be critical (Austin \& Hunter, 2013; Hasler \& Amichai-Hamburger, 2013). The most recent research indicated that even a year after the contact came to an end, pupils were reported as displaying 
more tolerance than matched pupils who had not been involved (Austin, Rickard, Austin, Smyth, \& Grace, 2014). In the context of Northern Ireland, the investment in the ICT infrastructure through a public-private partnership has brought the capacity of online contact within the reach of every child in every school; in other words, ICT provision opens up the potential for an approach that would include all children irrespective of the type of school they attend. Furthermore as part of the overall drive to encourage teachers to use ICT, the Department of Education in Northern Ireland has been steadily increasing its expectations that the use of ICT should be either accredited or assessed (CCEA, 2014). The requirements include the expectation that pupils will use ICT to exchange communication with others. In other words, using ICT to link to another school could fall within the framework of what was expected, and even required as part of the curriculum. Doing so might also serve as an inducement to teachers like those in Hughes' (2014) study who were attracted to the shared education experience by its potential impact on education outcomes.

\subsection{The research focus}

Our analysis of previous work on how best to enable young people in Northern Ireland to find ways of working together led us to formulate three research questions.

- How responsive were teachers to the idea of using ICT to work with another school and how did they feel about working with a student tutor as part of this process?

- What perceptions did student tutors form about the impact of this kind of work on the pupils they were working with?

- What did the student tutors themselves feel about their engagement with the project?

This final question was prompted by previous work (Austin \& Hunter, 2012) which had indicated that although students might be studying together at the university, they remained all too often in their cultural silos, avoiding contact with those perceived to be from "the other side." A project using ICT to link schools within Northern Ireland for joint work in the curriculum might provide a valuable experience of collaborative learning for the university students as much as for the pupils in school. In other words, this approach could be seen to meet the need to address division at two different educational levels. Furthermore, it seemed that while there is a consensus emerging around the potential value of the contact hypothesis in shaping the nature of online contact (Hasler \& Amichai-Hamburger, 2013), relatively little has been written about the role of facilitators in this process. Therefore the aim of this study was to understand the perceptions of teachers and university student tutors in using ICT, more specifically a virtual learning environment (VLE), to encourage community cohesion and student learning.

\section{Research context: epartners}

The epartners program was set up by the Ulster University in 2013-2014 as a partnership between the School of Education and the Department for Widening Access. With the support of the main churches, the agencies responsible for ICT provision in schools, (C2K), and the curriculum body which managed the accreditation of ICT (CCEA), a pilot scheme was launched with sixteen schools across Northern Ireland, including a number that were geographically isolated. The majority of these schools had taken part in a student placement program called Tutoring in Schools run by Ulster University (in which university students served as tutors in those schools which requested help with particular aspects of the curriculum). Past Tutoring in Schools projects have included literacy, numeracy, developing creativity and using ICT. However, the epartners project sought to use ICT in schools to connect and collaborate with another school in Northern Ireland through a VLE called FRONTER) with the assistance of university student tutors.

\subsection{Sample}

Sixteen schools participated in the project. Fourteen schools were partnered with schools that served a different religious community (five primary school partnerships and two post-primary school projects). The remaining two schools, both Catholic High schools, were partnered with each other on the basis of their common interest in the same subject area of the school curriculum.

Teachers from all schools attended a one day training session in November 2013 at which they met teachers from their partner school. Together, they were introduced to a Virtual Learning Environment called FRONTER and a video-conferencing system called Elluminate and discussed with their partner teachers an outline of the work they planned to do.

Thirty-one university students who had applied to take part in the epartners scheme were then allocated as tutors to ten of the sixteen schools. The geographical location of the schools did not always coincide with the students' place of residence so six out of the sixteen schools did not have the support of a university tutor. The tutors were also given training in January, 2014, before they began a thirty-two hour placement in their schools in early February. It should be noted that this placement was entirely voluntary for the students. The project came to a close in May 2014.

\subsection{Methodology}

This study uses survey data to examine teachers' and university student tutors' perceptions of ICT as a means to encourage community cohesion in Northern Ireland schools. Data were gathered from range of different sources including: (1) project teachers using an anonymous online survey at project's end; (2) an online discussion forum that served the university student tutors and; (3) case study material from the university tutors of two of the post primary schools involved in the project. Since the project was a small-scale first foray into unchartered territory, our intent has not been to provide firm conclusions about the impact of ICT in this environment, but rather to shed light on possibilities and to identify significant issues and questions for future research and implementation.

The epartners teachers' online survey (via FRONTER) included their perceptions of the effect of the epartners' program on their pupils' learning as well as on their own practice. Survey responses were received from teachers in eight of the sixteen project schools. We did not perceive any systematic differences between responding and non-responding schools so we believe that this limited response rate does give us a basis for addressing our modest research goals.

The student tutors' contributions to an online discussion forum (via FRONTER) during the thirty-two hour placement were designed to promote weekly reflections on their projects. Thirtyone students contributed to the weekly discussions. Results from both sources will be reported collectively.

The final data source was a case study to assess the attitudes of the student tutors on the project. The data were collected from the two post primary schools, out of the sixteen schools involved, on the epartners project. The case study approach was unique as no other studies to date have used university student tutors as support to teachers engaged in online delivery of a common curriculum across religious boundaries in a context of sectarian 
tensions. Case study material included: (1) student coursework evaluating the technology and their mentoring experience and (2) an open-ended student tutor questionnaire on evaluating the epartners project and; (3) an in-depth interview with the university lecturer coordinating the student tutors.

While there is research on video conferencing, on mentoring and on education in post-conflict societies, this study seeks to provide new insights on how VLE's can be used to encourage community cohesion. All procedures used within this study were approved by the Ulster University Ethical Committee, Parental, teacher and pupil consent was obtained from all subjects involved in this study and additional police check clearance was authorized.

\subsection{Case study: epartners pilot}

Two of the schools from the overall group of sixteen in the epartners program were selected to be the case study. Both schools, one predominantly Catholic in ethos and the other predominantly Protestant, have used academic selection at the age of eleven to determine who was given a place in the school. Both have a strong focus on academic achievement and for that reason, the parents, teachers and administrators in the schools would expect any innovation, such as epartners to be firmly rooted in the curriculum. In other words, these schools offered us the opportunity to see how an initiative designed to promote community cohesion could work in schools where teachers were likely to be under pressure to deliver academic goals. We reasoned that these schools provided a context in which, following Hughes (2014) the contact might serve the dual purpose of improving community cohesion and improving academic outcomes. It was agreed by the teachers and university staff involved in the program that the focus of the school pupils' work would be to design a nutritional and cost-effective meal which could be pitched to a potential supermarket chain. This fitted in both with the subject specialism of the university students and aspects of the required Northern Ireland Home Economics curriculum which was common to both sets of pupils (Key Stage 3). Drawing on research related to the contact hypothesis, and specifically on the importance of group to group interaction (Allport, 1954), the pupils were allocated to five groups in each school which matched similar sized groups in the other school. Each of these pupil groups were supported by university student tutors who visited the schools once a week to assist the pupils in logging onto FRONTER and using the discussion area to explore ideas for the dish they were designing in partnership with the other half of their group in their partner school. The culmination of this process was that pupils cooked their planned dish and then met together at the university as a combined team to make their pitch to a panel of judges for the best product concept.

The teachers' role was to ensure time each week was set aside within the class to use the technology and to encourage school pupils' participation within the project. The university students' role was, under the guidance of their university lecturer, to design weekly tasks for the pupils which would be uploaded to the content area of FRONTER. They were allocated to each of the two schools on a random basis, so that each school was supported by university students irrespective of any possible religious, cultural or political identity. The university student tutors were also responsible for designing assessment protocols for the pupils that were based on their product pitch, their contribution to the FRONTER discussion and their practical cooking skills. The university students' role also included all the planning for the product pitch competition which included the design of certificates, organizing ice-breaker activities, preparing food and evaluating the impact of the event. As part of the learning outcomes of the module university student tutors were also assessed based on their overall evaluation of FRONTER technology. The two schools agreed that because of the difficulty of scheduling classes at the same time, they would concentrate on using the asynchronous VLE rather than the synchronous video-conferencing. The actual work completed by the school pupils in FRONTER including the pupils' use of the forum and the wikis provided evidence of interaction and different types of learning.

\section{Analysis}

All data was transcribed, collated and imported into the qualitative data analysis software NVivo 10 (QSR International Pty Ltd, Victoria, Australia). A deductive approach was undertaken and a framework based on perceptions, attitudes and engagement of ICT on student learning, collaboration and community cohesion was applied. The sources of all verbatim quotes are displayed in brackets in terms of (i) gender; (ii) role on the project and (iii) data source.

\section{Findings}

The data were analyzed to see what evidence it provided related to the three research questions.

\subsection{First, how responsive were teachers to the idea of using ICT to work with another school and how did they feel about working with a student tutor as part of this process?}

At the start of the program, data from the online teacher discussions revealed that one hundred percent of the teachers stated said that in terms of using FRONTER they were either "very lacking in confidence" or "somewhat lacking in confidence." By the end of the program, seventy-five percent said they were "somewhat confident" with the remaining twenty-five percent saying they were "unsure." Similarly, eighty-seven and a half percent said that they thought FRONTER was either "somewhat effective" or "highly effective" as a means of establishing links with their partner school. In further comments, some teachers noted difficulties including "uploading pupils' work," that FRONTER was "not very intuitive" and "cumbersome" and that the school computers were "slow." Twenty-five percent of the respondents indicated that they had had no problems with FRONTER. In addition, results showed that one hundred percent of the teachers found the support of the university student tutors either "invaluable" or of "some value." Of those who did not have a student tutor one hundred percent said they would have liked one. Collectively these results indicated that teachers' perceptions of the technology and confidence in using the technology improved as they progressed throughout the program. In addition, the technology was perceived as a facilitator for encouraging community cohesion with other schools. However, technical issues and fear surrounding the technology prevented them from fully engaging with the program. Overall, in response to a question which asked to what extent epartners had helped teachers gain an understanding of how to use online learning with their pupils, eighty-seven and a half percent said either "considerably" or "very considerably." These results highlight that from the teachers' perceptions of technology FRONTER offered a platform for collaboration between schools from different sides of the community. In addition, results indicated that teachers' personal fear of using the technology prevented them from fully engaging with it. Having tutor support in the classroom helped to address this and encouraged them to engage in the program regardless of the religious divide. 
5.2. Second, what perceptions did student tutors form about the impact of this kind of work on the pupils they were working with?

Nearly all the university tutors contributed to an online discussion topic in which they were asked about how the teenage pupils felt about being linked to a school from a different background. A number of comments by tutors indicated that the pupils were indifferent to the fact that the other pupils were from a different religious background. As one of the university students noted, "any nerves on communicating to another school were based solely on the aspect that they were talking to new people they did not know" (Female/Male, student mentor, online discussion). They were much more concerned about whether the other pupils would see them and were reassured that initially, communication would be only by written text and that no pupil photographs would be shown. Naturally, given the range of personality types in both classes, the more lively pupils thought that video-conferencing would have been a good idea but since the classes were not timetabled at the same time this never took place.

As the project developed and the university students were able to overcome a range of technical issues to do with slow Internet speeds, limited access to hardware, a navigation system in FRONTER that was described by some as "not very intuitive," (Female student mentor, online discussion)some key insights emerged in pupil perceptions of the project. The first was that in spite of some of the challenges of using the school VLE, the student tutors noted how FRONTER was offering a 24/7 experience for most pupils, allowing them to study at their own pace and catch up if they ever missed a class. They commented on how FRONTER encouraged independent learning and allowed greater research on the chosen topics. As one university student put it, "pupils knew what they had to do and took responsibility for their learning." (Male, student mentor, online discussion)

Secondly, in a minority of cases, university students were surprised that the pupils had no previous experience of using FRONTER and noted that the lack of access to the Internet at home meant that some pupils felt excluded from the online discussions outside of the classroom. However, other results revealed that the university student tutors felt FRONTER was similar to the VLE used within their own university studies and this provided an opportunity to help school pupils make the transition from secondary to tertiary education. One participant stated, "In linking the two schools together, this will help prepare the pupils for higher level education and the workplace as they may be working with people they don't know." (Female, student tutor, discussion board)

Thirdly, university student tutors noted the motivational aspects of this kind off work for the pupils. As one university student noted, "the pupils... seemed to really enjoy the program. They were very enthusiastic especially when they were communicating with the other school." (Female, student tutor, online discussion) Another, who took the trouble to read around online learning, quoted Sanner and Dies (2009) to suggest that "collaboration can also encourage the academic success of culturally diverse pupils." The net result of the experience, was, according to one university student that "it boosted the pupils' self-confidence and also enabled them to meet others... from a different background and made them more open minded." These results indicate that ICT offers the potential to encourage collaborate, especially in preparing pupils for their transition from school to a university environment.

\subsection{Thirdly, what did the student tutors themselves feel about their engagement with the project?}

Comments by student tutors showed the same preoccupation as the school pupils with getting the task in hand done. For the school pupils the focus was on learning outcomes of the university module which was to develop a new food product for a supermarket retailer rather than deep cross-community understanding. For the university student tutors it was often coming to grips with the reality of working with pupils and problem solving on a range of fronts but especially using ICT in a classroom setting that were referred to most often. None of the student tutors commented specifically on the benefits to them of working on a cross-community basis though without exception, they said they had enjoyed being part of what they recognized as an innovative scheme that was of value to pupils and teachers. It should be noted that while the work was cross-community it was not designed explicitly to explore community relations but to promote the use of collaborative technology in the classroom. The university tutor directly involved with the students commented in an interview:

At the start of the program we discussed potential issues such as the religious divide between them and the pupils and between the two schools however the students did not foresee any issues and were excited to be a part of a cross community project.

[Female, university tutor, case study interview]

Furthermore, there is a longstanding cultural convention in Northern Ireland of polite avoidance of contentious issues (Austin \& Hunter, 2012). Religion was rarely mentioned among the student tutors as they focused primarily on using the project as an opportunity to gain teaching practice and develop their ICT skills. For some, who were wondering if teaching was a career for them, mentoring proved a validating experience; one said,

I have developed a real sense of what a career in teaching would be like and I have developed many new interpersonal skills as I have gained more confidence and better communication skills. I can now interact and engage with pupils successfully.

[Female, student tutor, case study interview]

\section{Another wrote,}

I learnt that controlling a classroom can be stressful and pupils may not want to listen, however I have been observing the teacher on how she controls a classroom effectively. Every day in the classroom was very different and there are many challenges that I faced but needed to overcome. Being prepared organized and constructing lesson plans are the key points in being a successful tutor.

[Female, student tutor, case study interview]

Just as experienced teachers sometimes grapple with integrating technology into their lessons, the student tutors noted the range of challenges this presented:

I have learnt the importance of understanding what you are doing because at the beginning the students needed a lot of help with using the FRONTER system so it was important that we as tutors were sure of how to use it. I have also learnt the importance of being prepared in case technology doesn't work.

[Female, student tutor, case study interview]

Quite apart from the need to be confident in the use of technology, one astute observer noted how ICT can introduce unexpected classroom management issues;

Another issue I came across was when the students were completing their work on computers, they had a tendency to hide behind their computers, leaving us slightly unaware of what they were completing. However, this was fixed by us in our groups engaging more with them and walking around to ensure they were completing the correct work in relative time. Showing another simple fix, so although the technology did pose some problems, they are easily solved.

[Female, student tutor, case study interview] 
These examples tell us something interesting about how students saw part of their role as being about problem solving, a key feature of what the university calls "graduate qualities." Beyond what we might call employability skills, some discovered personal qualities through the experience. One student tutor stated,

I did learn that as a tutor it was so important to be prepared each week, it helped with my confidence, feeling prepared helped me concentrate and convey confidence to the group. I learnt that young people like encouragement when they do something right and enjoy a tutor with a good sense of humor both of which I feel I had a good supply of!

[Male, university student, case study interview]

In summary, this evidence suggests that the apparent benefits of using ICT for the link between these two schools were largely instrumental; in other words, pupils gained ICT skills, successfully completed a piece of work together and gained experience that could be useful in either Higher Education or in the work place. Any improvement to community relations was a by-product of the other benefits. In addition, these results indicate that the FRONTER platform enabled the university tutors to collaborate effectively with the pupils as well as encourage the pupils in the partner school to collaborate together. Despite some initial nerves about being in the classroom environment and using a new technology the student tutors developed good working relationships with the pupils and the partner schools highlighting the use of such technologies to encourage cohesion within and outside the classroom environment.

\section{Discussion}

\subsection{Focus on task completion}

One of the most striking features of the case study was the way that teachers, university student tutors and pupils kept the focus of the interaction on the completion of the set tasks. Each team worked to create their own product, exploring with their university student tutors how to reach agreement on what would be the best concept and promotional approach to take to market the product effectively. In other words, this was a simulated exercise that was quite close to the kind of team work challenge that might be found in any workplace whether in Northern Ireland or elsewhere. Any issues of religious difference or identity were simply not part of the primary objective for these goal-oriented participants. Of course, we might expect a different result if dietary differences were an element of the religious difference (e.g., if the communities were Christian and Muslim), but that was not the case here. It is also worth noting that the case study took place in schools that agreed to participate on the basis of a clear understanding that there was a substantial academic element in the link.

\subsection{Links to the workplace}

We think that this example serves as a useful point to reflect on what the purposes of inter-school contact should be. While it can be argued that a fundamental purpose is to encourage children to become tolerant and respect diversity which are core principles of the citizenship element of the curriculum, there is also a need to prepare young people to be able to deal with this in the type of contexts where they are most likely to encounter difference and diversity. Some research indicates that this is much more likely to occur in the workplace rather than in the neighborhood or in social settings. Eyben, Morrow, Wilson and Robinson's work (2002) on creating work spaces that are respectful of diversity notes that Northern Ireland is characterized by a culture of "separation, avoidance and politeness" (p.13) and that the workplace is "one of the few places where people meet across lines of division." (p.12) In effect, the case study might suggest that enabling young people to deal with the kind of challenge they could face at work is an entirely appropriate goal for schools.

\subsection{Teacher preference for non-contentious work}

Furthermore, it seems that this kind of focus, i.e., working together on agreed aspects of the curriculum, has a good chance of winning the support of teachers. Many remain uncertain about how to handle sensitive issues in school links; in one of the other school links in the epartner program involving two primary schools, a university student noted the difficulties that can arise around the celebration of iconic figures. The patron saint of Ireland is St. Patrick and 17th March is a bank holiday in the Republic of Ireland and with some employers in Northern Ireland. In the past, St Patrick was closely associated with the Catholic/Nationalist/Republican elements of the population and while this is less true today, it presented a challenge for one of the student teachers.

She noted in her contribution to the online discussion that the children in her (Catholic) school wanted to know if they could wish their children in their partner school (non-Catholic) "Happy Saint Patrick's Day." She was told it would be inappropriate to do this as it "might be taken the wrong way." We can see this response as fitting into Eyben et al.'s (2002) assertion that avoidance and politeness often characterize discussion around potentially divisive matters. This reluctance of teachers to get involved in dealing directly with sectarianism has also been noted by Niens et al. (2013). According to their evaluation of a cross-community curriculum program, "teachers said that the children found the "sectarian aspect very difficult to understand" because they don't 'see themselves living in a sectarian world' and that by highlighting such issues the program was 'almost encouraging sectarianism." (p. 51). More broadly, Worden (2014) has drawn attention to the limited role that schools can make in shaping pupils' identity.

While we respect the view of those who wish to enable schools to change attitudes in young people, we think that a more modest but realistic and attainable target would be to focus on activities that use ICT to "normalize" relations between young people who have little contact with each other. In the interests of building trust, the curriculum focus for such links might start with work on topics which do not necessarily present challenges to pupils' identity. However, as part of a whole school strategy for promoting community cohesion, there should be support for those teachers who feel comfortable dealing with contentious issues in their subject area.

\subsection{The university student tutors' role}

While previous work has highlighted the critical role of teachers in managing the complex process of using ICT for community cohesion (Austin \& Hunter, 2013, p.12), we think it is timely to reflect on the contribution made by university tutors. We should note the positive views of the teachers about the assistance they provided and their desire to extend and continue this kind of partnership. Given the other pressures on teachers to complete required work for external examinations, it seems likely that they would not have been able to make the same use of the technology without the regular input of the university students. It is also clear that for the university students, the process of working as a mixed team to accomplish an innovative task in schools was a source of real pride experienced not just at an individual level but also as a group. 


\section{Conclusion}

Given what we have said about the depth of sectarian roots and its pervasive nature, we need to be realistic about what we can expect teachers to do to prepare young people for life after school. While acknowledging the need to be cautious in terms of the weight that can be attached to research on a pilot scheme in a relatively small number of schools, we think that four broad conclusions can be drawn from this study.

First, the use of technology, while not without some technical problems, can be used effectively as a link between schools, particularly when student tutors are involved and work alongside teachers and pupils. A culminating event, such as a face to face meeting at a neutral venue, such as a university, deepens the value of the ICT link.

Second, a strong focus on non-contentious areas of the curriculum has been shown to engage both teachers and pupils at a level that is not threatening and can provide a valuable platform for genuinely collaborative work which has clear academic value.

Third, the support of the churches and a range of other stakeholders in the epartners program has provided a valuable building block for further work. There have been many short term efforts to address sectarianism in schools but it will require wide-scale mobilization of many agencies to bring about a tipping point in these efforts.

Finally, the use of ICT with university student support offers a highly cost-effective means of harnessing existing resources, both human and technological, to address a problem which is a drain on the public purse and a barrier to community cohesion. At a theoretical level, it adds a further element to our understanding of the types of contact that are likely to be productive within the framework of the contact hypothesis. In that sense, although the focus for this piece of research is in Northern Ireland, we hope that it has resonance wherever the negative effects of separate and parallel lives can be mitigated by purposeful contact.

\section{References}

Akenson, D. H. (1970). The Irish education experiment: The National System of Education in Ireland in the nineteenth century. London: Routledge and Kegan Paul.

Allport, G. W. (1954). The nature of prejudice. Reading, MA: Addison-Wesley.

Austin, R., \& Anderson, J. (2008). E-schooling: Global messages from a small Island. London and New York: Routledge.

Austin, R., \& Hunter, W. (2012). Whatever you say, say nothing: Student perceptions of online learning and community in Northern Ireland. Irish Educational Studies, 31(4), 451-465.
Austin, R., \& Hunter, W. (2013). Online learning and community cohesion: Linking schools. New York and London: Routledge.

Barton, K., \& McCully, A. (2012). Trying to "See things differently:" Northern Ireland students' struggle to understand alternative historical perspectives. Theory $\mathcal{E}$ Research in Social Education, 40(4), 371-408.

Connolly, P., Purvis, D. \& O'Grady, P. J. (2013) “Advancing Shared Education” Ministerial Advisory Group <http://www.deni.gov.uk/shared-educationministerial-advisory-group.htm> Accessed: 5 December, 2014.

Council for the Curriculum, Examinations and Assessment. (2014). Northern Ireland curriculum. Belfast. <http://www.nicurriculum.org.uk/> Accessed 13 June, 2014.

Department of Education, Northern Ireland (1989). Education Reform Order.<http:// www.legislation.gov.uk/nisi/1989/2406/contents/made> Accessed 13 June, 2014.

Department of Education (2013a). Area Learning Communities. <http://www.deni. gov.uk/news/news-de-050813-area-learning-communities.htm> Accessed 13 June, 2014.

Department of Education (2013b), School Omnibus Survey - shared education. <http://www.deni.gov.uk/shared_education.pdf> Accessed 13 June, 2014.

Duffy, G. \& Gallagher, T. (2014). Sustaining school partnerships; the context of cross-sectoral collaboration between schools in a separate education system in Northern Ireland. Review of Education, 2(2), 189-210.

Eyben, K., Morrow, D., Wilson, D. \& Robinson, B. (2002). The equity, diversity and interdependence framework: A framework for organisational learning and development. University of Ulster.

Hargie, O., Dickson, D., \& Rainey, S. (2002). Religious difference, inter-group trust, attraction and disclosure amongst young people in Northern Ireland. International Journal of Adolescence and Youth (10), 213-235.

Hasler, B. S, \& Amichai-Hamburger, Y. (2013). Online intergroup contact. In Y. Amichai-Hamburger (Ed.), The social net. Human behavior in cyberspace (2nd ed. New York: Oxford University Press.

Hughes, J. (2014). Contact and context: sharing education and building relationships in a divided society. Research papers in education, 193-210.

Lecky, W. E. H, (1892). A history of Ireland in the eighteenth century. Online edition. <http://books.google.ca/books?vid=OCLC24603276\&id=mbsBAAAA MAAJ\&printsec $=$ toc\&dq=lecky+history+england\&sig=iU5UPyNpROTDXXJIFV 9 ucBDFVcE\&redir_esc=y\#v=onepage \&q=lecky\%20history\%20england \&f=false > Accessed 13 June, 2014.

Niens, U., Kerr, K., \& Connolly, P. (2013). Evaluation of the effectiveness of the "promoting reconciliation through a shared curriculum experience" programme. Belfast: Centre for Effective Education, Queen's University Belfast.

Northern Ireland Council for Integrated Education, Annual Report. (2012/2013). <http://www.nicie.org/wp-content/uploads/2013/11/NICIE-Annual-Report-201213-web.pdf> Accessed 13 June, 2014

O'Connor, U., Beattie, K., \& Niens, U. (2008). An evaluation of the introduction of local and global citizenship to the Northern Ireland curriculum. Council for the curriculum, examinations and assessment. UNESCO Centre, University of Ulster.

Rickard, A., Austin, R., Smyth, J., \& Grace, A. (2014). Assessing the impact of ICT enriched intercultural work on pupil attitudes: Evidence from the Dissolving Boundaries Program. International Journal of Information Communication and Technology Education, 3(10), 1-18.

Roulston, S., \& Young, O. (2013). GPS tracking of some Northern Ireland students: patterns of shared and separated space: Divided we stand? International Research in Geographical and Environmental Education, 22(3), 241-258.

Sanner, S., \& Dies, M. H. (2009). How can interdisciplinary collaboration between schools promote culturally diverse students' success? Academy of Educational Leadership Journal (13), 19-34.

Worden, E. A. (2014). National identity and educational reform. New York and London: Routledge. 